Multidisciplinary

SCIENTIFIC JOURNAL OF MARITIME RESEARCH

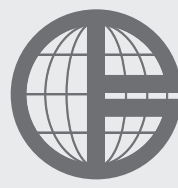

University of Rijeka

Faculty of Maritime

Studies Rijeka

\author{
Multidisciplinarni \\ znanstveni časopis \\ POMORSTVO
}

https://doi.org/10.31217/p.32.2.3

\title{
Yachts Passing by the West Coast of Portugal - What to Do to Make the Marina and the Destination of Figueira da Foz a Nautical Tourism Reference?
}

\author{
Luís Silveira ${ }^{1}$, Norberto Santos ${ }^{1}$, Fernando Perna ${ }^{2}$ \\ ${ }^{1}$ CEGOT / University of Coimbra, Colégio de São Jerónimo Largo da Porta Férrea, 3004-530, Coimbra, Portugal, e-mail: luis.silveira@uc.pt; e-mail: \\ norgeo@ci.uc.pt \\ ${ }^{2}$ School of Management, Hospitality and Tourism - University of Algarve, Campus da Penha, 8005-139 Faro, Portugal, e-mail: fperna@ualg.pt
}

\begin{abstract}
Yachting appears as a tourism segment with proven and specific importance for the economic and social development of tourist destinations Every year, thousands of yachts cross the Portuguese waters. Figueira da Foz is a seaside city and a destination with a history connected to tourism activities. Despite having a marina located in the city centre, the number of yachts stopping by is still far from this nautical port maximum capacity. As a reaction, and to change this reality, both local and regional stakeholders have participated in a Delphi panel to find out if yacht tourism has the potential to increase. It has been found that both the destination and its marina have the resources to attract and make this territory a nautical reference, and a strategy has been created. This model may serve as a basis for application in other nautical ports.
\end{abstract}

\section{ARTICLE IN FO}

Preliminary communication

Received 3 November 2018

Accepted 19 November 2018

Key words:

Yachting

Nautical tourism

Development strategy

Marina

Figueira da Foz

\section{Introduction}

Tourism is, in this $21^{\text {st }}$ century, a global activity and one that has the recognized ability to promote development in the territories where it happens.

Portugal enjoys a geographical position of undeniable potential at both European and world level. In the context of the Atlantic Ocean, there is a flow, mainly demarcated, from the area of the Panama Canal / Caribbean to Europe and North Africa, with entry to the Mediterranean Sea between these two continents, and where Portugal is located. However, the European seas have the largest flows of yacht traffic. The Mediterranean Sea, the North Sea and the Baltic Sea are the marine masses that present the largest flows of yachts, covering mostly the European continent. Exception to the western strip of Portugal, are Spain, France and Ireland, which are bathed directly by the Atlantic Ocean. According to Figure 1, Portugal occupies a central geographical position and stands in a location between the flows from the Caribbean, passing through the Azores to the Mediterranean, as well as the flow coming from Central and Northern Europe and going to the Mediterranean and the Caribbean (and vice-versa).

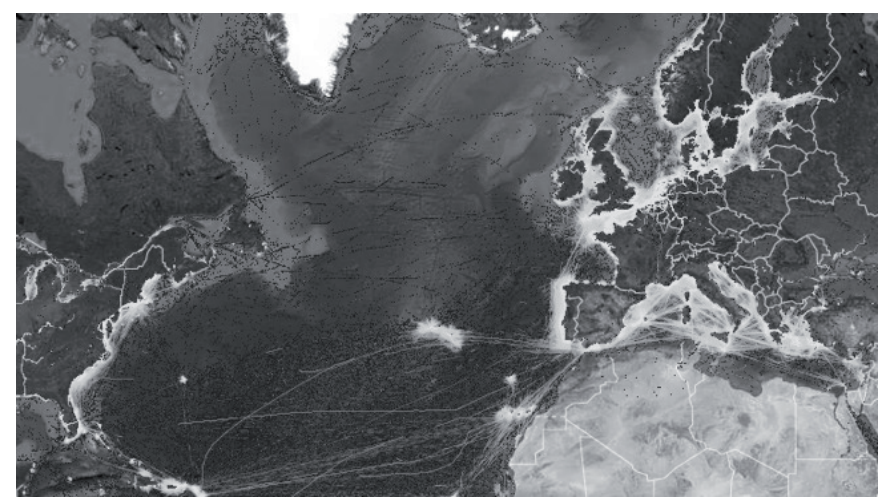

Figure 1 Yachts traffic in the North Atlantic (2014). The White / Clear Lines Represent the Flow of Yachts in the Seas and Oceans Visible in the Image. Source: Marine Traffic (2015)

Regarding the number of yachts on the Portuguese waters, there is no official statistical source to identify the quantitative dimension of vessels that annually pass along the Portuguese mainland, thus making it difficult to ascertain the potential market of tourists that may arrive by sea and on board yachts. However, some authors have presented some probable numbers. It is estimated that the 
Atlantic Portuguese coast is crossed annually by between 10,000 and 15,000 vessels [28]. According to the opinion of some owners of yacht sales companies [22], it has been mentioned that more than 20,000 yachts annually pass off the Portuguese coast. They have also pointed out that most of them do not enter in the marinas, sequencing the non-winnings of several million euros that will be collected by other countries.

Figueira da Foz has been an Atlantic seaside city and a destination with a history connected to the tourism activities since the $19^{\text {th }}$ century. Despite having a marina located in the city centre, the number of yachts stopping by ( 741 yachts in 2014 and 734 in 2015) is still far from this nautical port maximum capacity (344 berths). As a reaction, and to change this reality, both local and regional stakeholders have participated in a Delphi panel to find out if yacht tourism has the potential to increase and have formulated a strategy for yacht tourism development through a SWOT analysis, a set of interventional actions to be applied by in the municipality and in the marina. Adding to these measures, the characteristics for a future tourist product for yachtsmen have been presented. Some studies have been already made to enhance this tourism segment but mainly at national level (for example, Croatia [18], Turkey [25], among other). This research is (at least) the first one in Portugal to be applied at a municipality and marina structure level (local level) from the tourism perspective, using Delphi technique, and with the participation / involvement of stakeholders as yachtsmen, academia, public institutions, marina support managers, and leisure / tourism agents.

\section{Theoretical Background}

Water has always fascinated humans (it is, almost, an unconscious return to the liquid environment experienced during the gestation period). It was responsible for establishing the first populations and still continues to influence their distributions [20]. Water has also an almost magnetic attraction for tourists due to the availability of different scenarios for recreational and leisure activities [8] [15] [27]. Coastal areas have always been territories of intense human activity, long been associated to growth and development and have always had a significant economic function [24]. Coastal territories continue to be points of fascination with their meaning, of value to society, and with recreational and leisure function of extreme importance [10].

Concerning the long-range sportive nautical tourism or yacht tourism, the characteristics of this tourism segment have been presented [30]. They are: (1) recreational boats do not represent a mass displacement of passengers, being limited, predominantly, to the displacement of less than 12 people; (2) and which are not subject to fixed and regular routes, the itinerary being defined by the tourists themselves as an option and being susceptible to change by the passengers themselves; (3) and need shelter and mooring facilities for the berthing and stay procedure. For this last characteristics, the following goods and services are necessary or important at the place of destination and / or in transit: berth mooring for the vessel in a sheltered water area, provision of supply and catering, complementary supply (car rental, nightlife, etc.), and other services such as post office, tourist guides, etc. Nautical tourism, specifically yacht tourism, corresponds to sailing or navigation of small and medium-sized sailing and / or motor yachts by individuals (potentially tourists) who navigate using the sea environment and who use points in coastal zones for rest, fuel and food supplies, and for the use, generally in the immediate vicinity, of infrastructures and services that may or may not have a tourist vocation. In some countries, the nautical stop points may be more diverse than those in Portugal, such as anchoring in bays or coves. This situation is more common when the shoreline is trimmed and protected from rippling. The Portuguese mainland coast is little cut and is at the mercy of the Atlantic. In this sense, marinas and recreational ports are the main points / infrastructures for receiving yachtsmen and their vessels [26].

Regarding the marinas, it can be pointed out that these have been the means of supporting recreational craft and have been developing in maritime countries as a way of attracting people engaged in different forms of navigation. Its growth in the last decades shows the importance both as catalysts for the growth of leisure equipment (hotels and recreation) and for instruments to revitalize tourist resorts and coastal towns [5].

Yachting appears as a tourism segment with proven and specific importance for the economic and social development of the destination Yacht tourism is considered as one of the most propelling types of recreational tourism. Thanks to its multiplier effects, it contributes to a more valuable and versatile quality of life and planning, opening the way to other effects, directly or indirectly, linked to a global destination humanization [12]. In addition, and according to some reports and authors [9] [17] [23], yachtsmen are a welcome tourist population for those destinations with marinas, being high academic educated and with high buying power. The average daily expenses per yachtsman in the Algarve (Portugal), Balearic Islands (Spain) and Croatia are of €115.40, €171.10 and €99.92 respectively.

\subsection{The Territory and the Marina}

Figueira da Foz corresponds to an integrated municipality in the Portuguese Centro region, with an area of $379.4 \mathrm{~km}^{2}$, located along the West Atlantic coast, $180 \mathrm{~km}$ North from Lisbon. In terms of population, Figueira da Foz was, in 2011, the sixth largest municipality in the region, with 62,125 inhabitants [11].

The territory corresponding to Figueira da Foz was occupied very early due to the strategic location between the Atlantic Ocean and the Mondego River estuary. In the 18th and 19th centuries, Figueira da Foz grew in importance 
at national level due to the movement of the port and the shipbuilding industry, having been elevated to the category of a city in 1882. At the end of the nineteenth century there was also another economic impulse, originated by the arrival of aristocrats for the usufruct of the waters of the beaches and of the coast, as well as the coming of Spaniards with great purchasing power; They would also come for gambling reasons, flocking to the casino (the oldest of the Iberian Peninsula) [29], having simultaneously held five casinos during the Belle Époque period.

It is said [21] that (in relation to cities with beaches), in the last decades of the 19th century, Portugal saw the alteration of these 'places of distinction' restricted to leisure practices among the elites. The thermal zones and villas, in the surroundings of the urban centers, places predominantly consigned to the leisure, are gradually replaced by the seaside zones. These changes, resulting from the approximation of the population to the sea baths and the consequent seasonal installation in the coastal zones, would modify some Portuguese coastal landscapes and sociality among the Portuguese high society, resulting in new uses of personal time and areas confluent with the sea and rivers [2]. The tourist vocation of Figueira da Foz has been increasing over time as a destination for the sun and beach product, resulting in a city with a varied offer of accommodation, as well as a diverse set of equipment that support and are part of the tourist offer [4].

The marina of Figueira da Foz is located at the latitude $08^{\circ} 52^{\prime}$ North and $40^{\circ} 09^{\prime}$ West. It is placed at the mouth of the river Mondego and at $0.7 \mathrm{M}$ (nautical miles) of the seaside breaks. It belongs to and is managed by the Seaport Authority of Figueira da Foz. The marina has an entrance with 100 meters, facing south and has a dry area with $50,000 \mathrm{~m}^{2}$. It was built in 1995 , and has increased in capacity, in 2012, from 273 to 344 berths (plus 71 berths). The nearest marinas are located $31 \mathrm{M}$ North (Aveiro) and 34 M South (Nazaré). This marina has a dual functionality, being used both by resident and visiting boats. In 2015, there were 131 yachtsmen who had signed annual con- tracts of mooring their boats in that structure, that number being stable for the last years. The marina is visited by yachtsmen whose numbers have been generally stable with a variation of 64 boats between the year with the least number of passengers (2013) and the year with the largest number of them (2014). In 2012, there were 686 yachts and in 2013 there were 677 yachts. By the year 2014 , the number had risen to 741 crafts, and by 2015 , the number was of 734 yachts (Figure 2).

There is a monthly movement of yachts throughout the year although there is a direct relationship with the low and high seasons of the northern hemisphere (winter vs. summer). However, the so-called yachting season has the particularity, for example, of sun and beach tourism (midJune to mid-September), to start earlier and to finish later, being responsible for the reduction of seasonality. Yacht tourism is a selective form of tourism that ensures at least 180-210 days per year of related economic activities [12]. As it can be seen in Figure 2, between the years 2012 and 2015, a notorious growth begins in April, reaching the peak in the month of August, and maintaining a flow almost constant until October. In the months of August, there were 162 yachts in 2012, 171 in 2013, 195 in 2014, and 175 yachts in 2015. The month of October also showed a considerable flow, and compared to the month with the lowest representativeness (January: $2012=0,2013=5,2014=2,2015$ = 1), with the number of visitors in 2012 being 42 yachts, 2013 with 26 yachts, 2014 with 50, and 2015 with 33 recreational boats (data concerning 2016 and 2017 it still not available from the Seaport Authority). Between the year 2012 and 2015, the top five most represented countries through skippers' residence were France, United Kingdom, Germany, the Netherlands and Portugal. In the total of the Centro region and about the number of overnights in hotel accommodations, the most represented countries were, in 2016, Portugal (56.9\%), Spain (11.9\%), France (6.7\%), Brazil (2.9\%) and Germany (2.8\%) [3]. In that sense, nautical tourism can be used to attract new markets, namely the United Kingdom and the Netherlands.

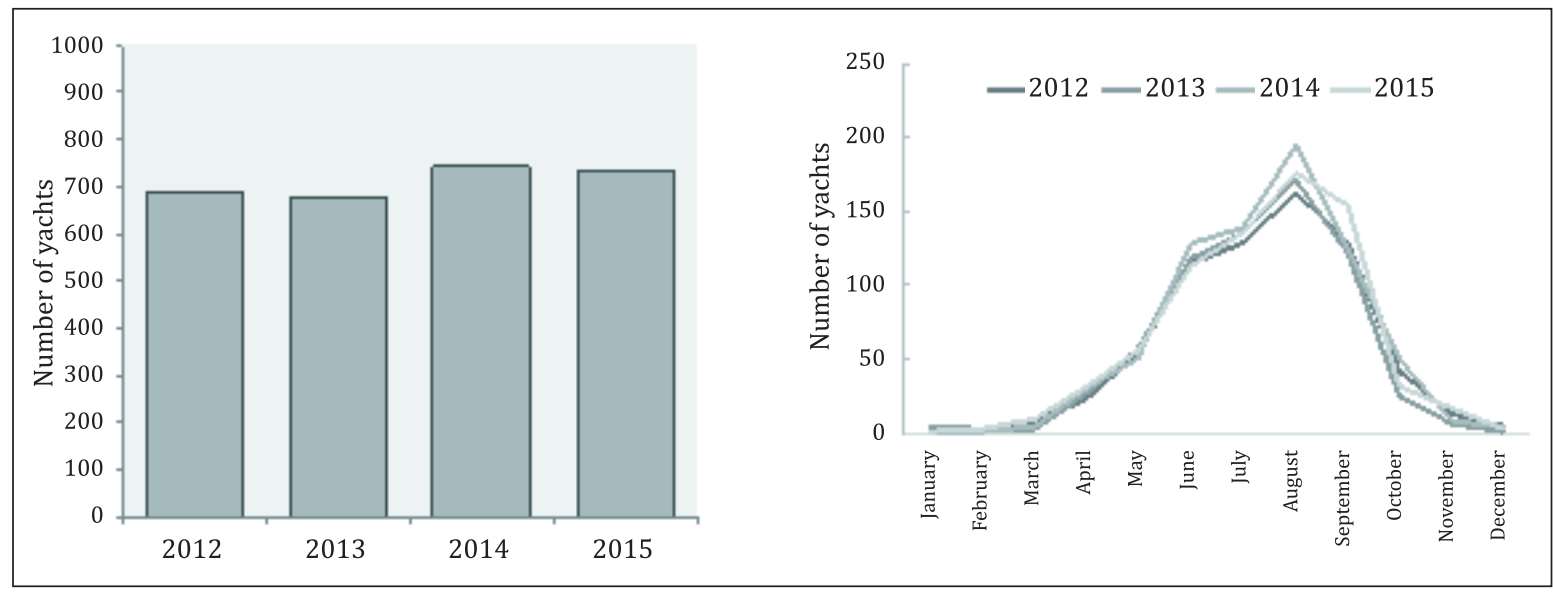

Figure 2 Total Number of Yachts and the Distribution by month in 2012, 2013, 2014 and 2015. Source: created from data collection in the Seaport Authority of Figueira da Foz (2016) 


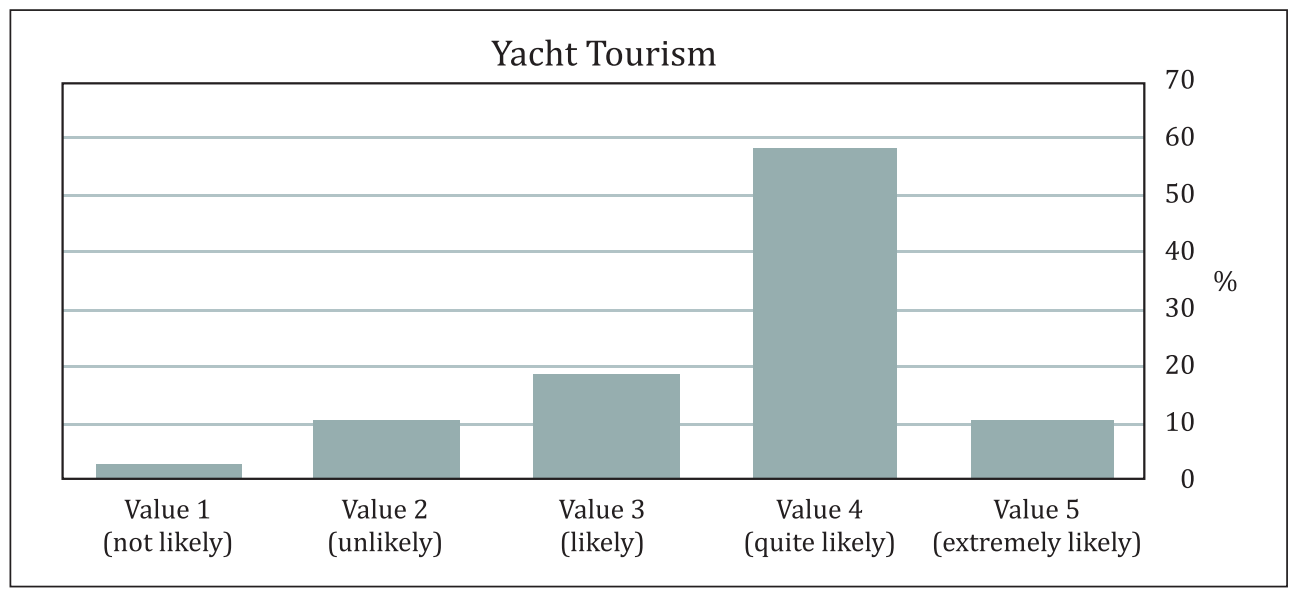

Figure 3 Probability of Yacht tourism Development in Figueira da Foz Source: Silveira (2016)

\section{Method}

The research carried out a strategy that can be created to enhance yacht tourism in this city. In addition to a literature review and a data collection at the Seaport Authority of Figueira da Foz, a Delphi qualitative method has been used. This technique can be characterized as a method for structuring a communication process of a group of experts, thus allowing that group as a whole, but separately, to deal with a complex problem under study. It comprises the analysis of qualitative data, obtained scientifically from the opinions / knowledge / experiences of several specialists in a certain area of society knowledge. They are strategically selected according to their scientific / governance / technical areas of action or intervention, and the territory under study [1] [6] [7] [13] [14] [19].

The application of the method occurred through the inclusion of 41 experts grouped in (1) public agents and academia, (2) marina support agents and local yachtsmen, and (3) leisure and tourism agents. The procedures have been divided in three rounds, using online questionnaires and the participation has been anonymous within the group to ensure the inexistence of group pressure and answers influences. From round to round some questions have no longer been asked since a consensus has been achieved (more than 50\%). The results have been included in a SWOT analysis, a set of short and medium/ long term interventional actions in Figueira da Foz, a set of short and medium/long term interventional actions in the local marina, and the characterization of a future tourist product for the visiting yachtsmen.

\section{Results and Discussion}

Assuming the reality by specialists that the marina and, consequently, Figueira da Foz is not getting a remarkable traffic of yachtsmen, the probability of the destination to develop as a hub of this type of tourism has been asked for. In this sense, it has been verified that $68.5 \%$
(V4=57.9\%+V5=10.6\%) of the respondents consider as quite to extremely likely the development of yacht tourism if a strategy is implemented by the local stakeholders (Figure 3).

The support reasons are: (1) the marina is in the city centre; (2) strategic location (national and international scales); (3) existence of sites with potential to implement nautical specific services; (4) possibility of navigation throughout the year; (5) proximity to road and rail networks; and (6) proximity to other (complementary) tourist destinations. Identifying the general elements, enhancers and differentiators, of the destination and its future relationship with nautical tourism, a systematization is done through a SWOT analysis, an identification of several intervention actions and the characterization of a future tourist product.

Part of the results that have been achieved to build a yachting development strategy have been implemented in a SWOT analysis. This method is considered a strategic planning tool commonly used by companies and organizations. When identified the four quadrants (Strengths, Weaknesses, Opportunities and Threats), allow decision makers to think of the ways to maximize Strengths and use them to minimize Weaknesses (internal environment); in this case, intrinsic to the municipality of Figueira da Foz. At the same time, and in relation to external factors/environment, the purpose is to take advantage of Opportunities for the elimination or minimization of Threats (external to the municipality). These results are fundamental for the definition of a planning base. Specialists from Delphi panel identified 13 strengths being safety in the top five and as the factor that is most related to the destination (Table 1). Portugal is one of the world safest countries and Figueira da Foz, as a small-/medium-size city (in the Portuguese context), has a very low crime and incidents rate. The national geographic context is the strength since Figueira da Foz is located between the two metropolitan areas of Lisbon and Oporto and $56 \mathrm{~km}$ distant from Coimbra, the region capital; Figueira da Foz is, as well, the largest and most important seaside city between the met- 
Table 1 The Top Five Strengths and Weaknesses of Figueira da Foz

\begin{tabular}{|l|c|l|l|}
\hline \multicolumn{1}{|c|}{ Strengths } & $\%$ & \multicolumn{1}{c|}{ Weaknesses } & \multicolumn{1}{c|}{$\%$} \\
\hline Safety & 66.7 & Lack of a local tourism strategy & 42.4 \\
\hline National geographic context & 48.5 & Lack of marina support services & 39.4 \\
\hline Availability of land for a nautical cluster & 48.5 & Weak tourist promotion & 36.4 \\
\hline International geographic context & 39.4 & Limited river's navigability & 30.3 \\
\hline Hospitality & 39.4 & Lack of a frequent yachtsmen program & 30.3 \\
\hline
\end{tabular}

Source: Silveira (2016)

ropolitan areas. Related to the present and future nautical activity, available is a land at the south river bank (marina located at the north) to invest in economically. Since the yachting main markets, being the Netherlands, the United Kingdom and Germany are facing a lack of marina berths and services support structures, this can be a relevant fact. Internationally, Figueira da Foz has, in its geographic location an advantage since it is a seaside municipality, located near the important and international maritime route for yachts that cross the Portuguese waters. As for its tradition related to tourism and as a typical of all smaller cities, hospitality is determined as a strength and can be determinant for the tourists stay overall satisfaction.

The five most identified and selected weaknesses (from a total of 23) start in a lack of a local tourism strategy. There is the finding that neither the municipality nor the marina management entities have a specific and planned strategy, at least in a long-term, to deal with both sun, sea and sand tourism (main segment) and with nautical tourism as well The second scored weakness is the lack of a more complete and diversified offer of services in and by the marina and by the stakeholders. The tourism promotion abroad can be an important way to establish tourist flows to the destinations. The assessment is that Figueira da Foz has a weak action abroad in selling the destination (third weakness). The fourth weakness, the limited Mondego river's navigability, could be an advantage to promote river sailing and other nautical activities but since there is a large accumulation of sands, the navigability is limited to the section river mouth - marina. Finally, a program is missing or a service that could enhance the nautical tourists / yachtsmen stops, their stays and to make them see the advantages in coming back in upcoming opportunities.

Sixteen opportunities have been identified to potentially enable nautical tourism in the municipality. From these, the five most selected have started with the proximity of Figueira da Foz to other important destinations (Table 2) specialized in different tourist segments of the region such as Coimbra (cultural tourism / its university and historic centre listed as UNESCO World Heritage). Other destinations, such as Bairrada (wine and gastronomy), Conímbriga (archaeological tourism), Lousã (rural and mountain tourism) and Fátima (religious tourism) can offer different possibilities of serving as complementary destinations of the Figueira da Foz tourist offer. The potential and emerging tourist markets of Russia, Brazil and China are an opportunity to the tourism development in this Portuguese destination. With a diversified offer of tourist products and destinations, there is a possibility to create/enhance tourist routes, as for example Figueira da Foz (nautical tourism) - Coimbra (cultural tourism) - Fátima (religious tourism). Different routes can be adapted to each tourist's available time (a morning, a day, two days, etc.). There is the assumption that foreign investment can be an opportunity as well the existence of European Union (EU) funds to support the nautical structures. The fifth scored opportunity refers to the potential of promoting Figueira da Foz as a nautical destination at specific and related fairs.

Regarding the threats, there is not a regional strategy in order to plan and to encourage yachting in the Centro region (where the municipality belongs to) and that can compromise the overall development. The absence of predispositions and initiatives or the absence of a triple helix

Table 2 The Top Five Opportunities and Threats of Figueira da Foz

\begin{tabular}{|l|c|l|l|}
\hline \multicolumn{1}{|c|}{ Opportunities } & $\%$ & \multicolumn{1}{c|}{ Threats } \\
\hline $\begin{array}{l}\text { Proximity destinations such as Coimbra, Conímbriga, } \\
\text { Bairrada, Lousã and Fátima }\end{array}$ & 66.7 & $\begin{array}{l}\text { Lack of a regional strategy for the development of } \\
\text { nautical tourism (yachting) }\end{array}$ & 57.6 \\
\hline Potential and emerging tourist markets & 63.6 & $\begin{array}{l}\text { Absence of predisposition and initiatives between } \\
\text { internal and external agents; }\end{array}$ & 54.5 \\
\hline $\begin{array}{l}\text { Development of tourist routes (Figueira da Foz - Coimbra } \\
\text { - Fátima) }\end{array}$ & 48.5 & Lack of knowledge from decision-makers \\
\hline $\begin{array}{l}\text { Foreign investment and European funds to support the } \\
\text { nautical structures }\end{array}$ & 48.5 & Conflicts between entities on public territorial areas & 45.5 \\
\hline Promotion at nautical fairs & 45.5 & Lack of a national nautical culture & 45.5 \\
\hline
\end{tabular}

Source: Silveira (2016) 
model (public, private and academic/community) is the second identified threat. Adding to this absence, a lack of knowledge from decision-makers can be the result. Since the management of nautical structures can be carried on by private entities, at the same time the coastline is of public/state domain which can result in bureaucratic conflicts. In an overall perspective, there is the perception that there is a lack/poor national nautical culture which limits the creation of a critical mass and the consequent demand for improvements in this area.

The interventional actions which will allow the development of yachting should be implemented by and at the destination and at the marina levels. For each of these territorial elements or management structures, actions of short (one year) and medium / long term (need two or more years) should be implemented. With a Likert scale to analyze the importance $(0=$ the least important and $10=$ the most important) of each action, a mean $(\bar{X})$ has been achieved (Table 3).

In what concerns to Figueira da Foz, and, in short terms, the primary action should be the initiative to promote the destination in places related to the main markets of nautical tourists. These sites refer more specifically to coastal cities with marinas from countries such as France, the United Kingdom, the Netherlands and Germany. It will be important to publicize the destination and make it an option on a planned voyage. The second short-term action states the importance of encouraging the organization of nautical events such as regattas. This type of events, usually on a yearly basis, allows the sedimentation and recognition of destinations over the years as they become known and reach a growing potential population of participants. The third action consists of the placement of an interactive terminal with tourist information or the presence of a person from the city tourism office. Although the tourist office of Figueira da Foz is relatively close to the marina, there are many yachts arriving at the marina by sea and only when they check in they decide for how long they will stay. Others enter the marina only for bunker, because there are no attractions or motivations to make them stay. The existence of tourist information could be an incentive to prolong the stay.

Regarding medium- / long-term measures, the municipality might incur incentives for attracting foreign investment to the training of local companies related to nautical tourism, making them more competitive. The second measure will also take some time until the results are collected, but that can bring significant benefits. That involves the training of human resources and local agents in matters related to recreational boating. The third most important measure is the coordination of strategies with international operators, allowing the municipality to appear in their databases and in the action fields of these companies, for instance in the real estate markets (second residence of boats) and the purchase and sale of boats.

Referring to the marina and in short terms, the most important action to consider refers to the provision of $a$ permanent VHF (Very High Frequency) call service allowing the possibility of communication at any time between vessels passing off the coast and the marina (Table 4). Considering the configuration of the marina, it is organized in two main fingers with access to land through the

Table 3 The Main Short- and Medium-/Long-term Interventional Actions in Figueira da Foz

\begin{tabular}{|c|l|c|}
\hline \multicolumn{2}{|c|}{ Figueira da Foz } & $\bar{X}$ \\
\hline \multirow{4}{*}{ Short Term } & Promotion of the destination in northern and central coastal Europe & 7,91 \\
\cline { 2 - 4 } & Incentive/support the organization of international nautical events & 7,77 \\
\cline { 2 - 4 } & Tourist information service facility in the marina & 7,38 \\
\hline \multirow{3}{*}{$\begin{array}{c}\text { Medium / } \\
\text { long Term }\end{array}$} & Attraction of external investment to companies related to the nautical activities & 8,10 \\
\cline { 2 - 4 } & Promote technical development of local agents & 8,09 \\
\cline { 2 - 3 } & Strategies coordination with major international operators & 8,06 \\
\hline
\end{tabular}

$0=$ the least important and $10=$ the most important

Source: Silveira (2016)

Table 4 The Main Short- and Medium-/Long- term Interventional Actions in the marina

\begin{tabular}{|c|l|l|}
\hline \multicolumn{4}{|c|}{ Marina } & $\overline{\boldsymbol{X}}$ \\
\hline \multirow{4}{*}{ Short Term } & Permanent answering service to VHF calls & 8,58 \\
\cline { 2 - 4 } & Building a direct access between the west boardwalk and the reception/toilets & 8,56 \\
\cline { 2 - 3 } & Regular cleaning of the marina and the surrounding waters & 8,47 \\
\hline \multirow{3}{*}{$\begin{array}{c}\text { Medium / } \\
\text { long Term }\end{array}$} & Incentives for fixing repair and boat wintering enterprises & 8,34 \\
\cline { 2 - 3 } & Offshore promotion of these enterprises & 8,28 \\
\cline { 2 - 3 } & Improvement of the navigation conditions at the river mouth & 8,19 \\
\hline
\end{tabular}

$0=$ the least important and $10=$ the most important

Source: Silveira (2016) 
opposite ends (East - West) and with a main building (reception, laundry, changing rooms) and fuel supply located to the North, the second short term to take place in the marina would involve the construction of a footbridge linking the west bridge to the main building. This measure would increase the comfort of the users, due to the reduction of the route to be carried out on foot. The third measure to be implemented is to safeguard the environment and aesthetics of the land and sea spaces associated with the marina through regular cleaning and maintenance.

Regarding the medium- / long-term measures, the importance of the Seaport Authority (which also manages the marina) is focused on the creation of incentives and advantages for the attraction of companies related to boat repair and wintering. As a complement to the previous measure and in order to the already existing business sustainability, the continuous external promotion of these services would be important. The third most quoted action consists of improving and maintaining the navigability between the entrance of the marina and the entrance of the river bar through dredging sands, allowing the increase in the depth of and the consequent stability of the ripple.

In order to enrich the destination capacity of developing yachting, a specific tourist product can be created (Table 5). In general terms, the future product may include the provision of tourist circuits that involve different types of tourism, such as urban cultural (Coimbra Unesco World Heritage Site - Universidade, Alta e Sofia), gastronomic and wine (Baixo Mondego, Bairrada and Serra da Lousã), rural (Aldeias de Xisto), historical (Castelos e Muralhas do Mondego, Quinta das Lágrimas - Lenda de Pedro e Inês - Óbidos) and religious (Coimbra - Rainha Santa Isabel, Irmã Lúcia and Santo António of Pádua - and Fátima), and can be planned even in the slope of high added value (luxury). Together with this level of quality, the inclusion of exclusivity in the offer of services, such as diving and surfing, and many others, can be a good promotion.
The tourist product should be appropriate to the different types and lengths of stays and the transport to be included in the offer must be practical and functional. The product to be offered should not be dissociated from the nautical side and, therefore, some experts have included annual nautical events, specialized repair works, the creation of a training centre or nautical school and, even, the creation of a nautical city (as, for example, in the case of Auckland where part of the city, in the riverside area, includes concentrated services of nautical support and services of leisure) [26]. The product itself should include its promotion abroad and link it to the destination through a characteristic that is unique to it. On this same singularity, as questioned, ten uniquenesses associated with Figueira da Foz have been identified. There are the trilogy (1) Boa Viagem Mountain - River Mondego - Sea; (2) the favorable conditions (constant winds) throughout the year for the practice of different water sports; (3) the largest beach in Portugal is located in Figueira da Foz; (4), the salines and their unique characteristics on the left river bank of the Mondego; (5) the location of the marina in the centre of the city; (6) the proximity and accessibility to other tourist destinations; (7) the existing forests, marshes and ponds; (8) the longest wave in Europe (an advantage for surfers); (9) the gastronomy (fresh fish all year round); and (10) the oldest casino on the Iberian Peninsula.

The tourist product in question should be formulated and combined at different scales, ranging from the local scale to the international one, through the sub-regional (inter-municipalities), regional and national scale. On the territories to be involved in the creation of this product at various scales, the participants have suggested the involvement of two countries: Spain and Portugal. In the first case, it refers specifically to the regions of Castilla y León and Extremadura; the Spanish regions bordering the central region of Portugal, more specifically the population closest to the border and from where the Portuguese

Table 5 Characteristics to be Included in a Future Tourist Product for Yachtsmen

\begin{tabular}{|l|c|}
\hline Yachtsmen tourist product characteristics & $\overline{\boldsymbol{X}}$ \\
\hline Specialized naval repair services & 8,58 \\
\hline Holding annual nautical events & 8,03 \\
\hline Promotion abroad of Figueira da Foz uniquenesses & 8,00 \\
\hline Training centre / nautical school & 7,74 \\
\hline Targeted product for different types and durations of stays & 7,69 \\
\hline Offering practical and functional transport & 7,58 \\
\hline Creation of a nautical city & 7,42 \\
\hline Offering exclusive services (diving, surfing, etc.) & 7,35 \\
\hline Cultural tourism (Coimbra) & 7,25 \\
\hline Gastronomy and wine tourism (Bairrada) & 7,25 \\
\hline Luxury travel circuits & 6,78 \\
\hline Religious tourism (Fátima) & 6,28 \\
\hline
\end{tabular}

$0=$ the least important and $10=$ the most important

Source: Silveira (2016) 
Table 6 Entities to Be Involved (and Leadership) in the Creation of a Specific Tourist Product for the Yachtsmen

\begin{tabular}{|l|c|}
\hline Entities & \% \\
\hline Seaport Authority of Figueira da Foz (leadership) & 90.6 \\
\hline Centro Region Tourism (leadership) & 87.5 \\
\hline City council (leadership) & 81.3 \\
\hline Nautical clubs & 81.3 \\
\hline Nautical associations & 75.0 \\
\hline Restaurants and catering businesses & 71.9 \\
\hline Hospitality entrepreneurs & 71.9 \\
\hline Companies of tourism recreation & 71.9 \\
\hline Retail entrepreneurs & 65.6 \\
\hline Tourism of Portugal & 56.3 \\
\hline
\end{tabular}

Source: Silveira (2016)

Atlantic coast is the territorially closest sea front. In the second case, in relation to Portugal, the Centro region should naturally be one of the territories involved, both as a whole and under the sub regional aspect, namely Dão-Lafões (Viseu as a reference municipality) and the vineyard sub-region of Bairrada (with the municipality of Mealhada to take a role of reference).

The importance of including the territorial space that surrounds all the seaside municipalities between Aveiro and Nazaré has been identified and seen as a whole. The metropolitan areas of Oporto and Lisbon have been also named for their capacity for tourist attraction, buying power, the already existing transport infrastructures and marketing. From the municipal point of view, municipalities with consolidated or potential tourism products have been identified: Montemor-o-Velho, Coimbra, Pombal, Leiria, Fátima and Óbidos.

Regarding the agents/entities which should or can be involved in the creation of a specific tourist product for the yachtsmen, ten entities have been nominated by most of the specialists (Table 6). Out of these, the Seaport Authority of Figueira da Foz, the Centro Region Tourism and the City Council have been designated to take the leadership of the group.

\section{Conclusion}

Yacht/nautical tourism has proved to be one of the types of tourism that has been growing with prospects of continuing in the coming years. In order to benefit from local destinations, from the cities where the marinas are located and, consequently, at the national level as well, it is important to train and adapt supply to demand. Yacht tourism is emerging as a segment with a small market, unlike other types of tourism, such as Sun, Sea and Sand. As a counterpoint, it has presented higher levels of sustainability in the different aspects included in it, as well as it has demonstrated a stable and balanced growth in relation to the supply in the destinations, allowing them to make a sustained and effective planning. It has been acknowledged that there are conditions in the destination and the local marinas, as well as a favorable appropriation of the characteristics of the market and of the yacht tourism activity itself, so that it can develop in this territory. In addition, the importance of the creation and the supply of a specific tourist product for the yachtsmen passing by has been verified. In this sense, among the recommended characteristics to be included in the future product, a specialized naval repair offer has to be included, the need to promote abroad the singular elements of Figueira da Foz and joining the annual nautical events that can and should be organized at the destination (both as motivation enhancers for the arrival and stay of yachts).

Regarding future developments on yachting in the Centro of Portugal region, it will be of utmost importance to study permanently the potential dynamics between the Figueira da Foz, Nazaré and Aveiro marinas, with the possible creation of a plan or a strategy which would help to create a scale of, especially at international level. Two out of the three designated stakeholders and leaderships (chosen from this research), specifically the Seaport Authority of Figueira da Foz and the City Council, welcomed the results presented and committed to integrate this strategy as local/municipal vector in the context of the future nautical station (formed by 11 regional municipalities). This future nautical station together with its application is in course of its development and will be presented to the national certifier, the Fórum Oceano, in 2019.

This development model, presented in this paper, may serve as a basis for application in other nautical ports.

\section{Acknowledgments}

This work has been co-financed by the European Regional Development Fund (ERDF) through the COMPE TE 2020 - Operational Program Competitiveness and Inter nationalization (POCI) and national funds by FCT under the POCI-01-0145-FEDER-006891 project (FCT Ref: UID / GEO 04084/2013).

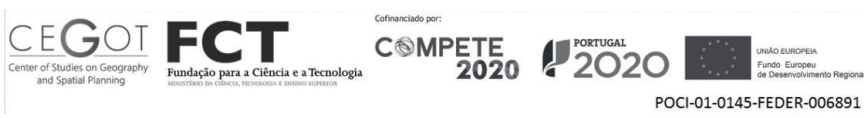




\section{References}

[1] Brady, S. (2015) Utilizing and adapting the Delphi method for use in qualitative research. International Journal of Qualitative Methods, 2015, pp. 1-6.

[2] Cascão, R. (2000) A invenção da praia: notas para a história do turismo balnear. In: M. C. Coelho, ed., O campo e a cidade. Colectânea de estudos, 1st ed. Coimbra: Centro de História da Sociedade e da Cultura / Edições Magno, pp. 321-341.

[3] CIITT - Centro Internacional de Investigação em Território e Turismo. (2017) Impactur. Indicadores de monitorização e previsão da atividade turística - Relatório anual 2016 Centro. Faro: CIITT. Available at: http://www.ciitt.ualg.pt/ impactur/relatorios/PT/16/A201625516_230252317/ A201625516_230252317_pr.htm.

[4] CMFF - Câmara Municipal da Figueira da Foz. (2014) Figueira 2030, território sustentável do atlântico, Figueira da Foz: CMFF.

[5] Cunha, L. (2009) Introdução ao turismo, 4th ed. Lisboa - São Paulo: Editorial Verbo.

[6] Faucher, J.-B., Everett, A., \& Lawson, R. (2008) Applying a modified Delphi approach to determine the current state of the concept of knowledge. In: 39th Annual Meeting of the Decision Sciences Institute. Baltimore: Decision Sciences Institute, Vol. 3, pp. 4801-4806.

[7] Garrod, B., \& Fyall, A. (2005) Revisiting Delphi: the Delphi Technique in tourism research. In: B. W. Ritchie, P. Burns, \& C. Palmer, eds., Tourism research methods: integrating theory with practice. Cabi Publishing, pp. 85-98.

[8] Gonçalves, A. (2010) Still waters run deep in Cardiff bay: tourism on "Europe"s most exciting waterfront development. In: E. Brito-Henriques, J. Sarmento, \& M. Lousada, eds., Water and tourism - Resources management, planning and sustainability, 1st ed. Lisbon: Centro de Estudos Geográficos, Universidade de Lisboa, pp. 71-92.

[9] Govern de les Illes Balears - Conselleria de Turisme. (2007) El turismo náutico en Balears 2007. Palma de Mallorca: Govern de les Illes Balears - Conselleria de Turisme.

[10] Hall, C. M., \& Page, S. J. (2006) The geography of tourism and recreation - Environment, place and space, 3rd ed. London and New York: Routledge.

[11] INE - Instituto Nacional de Estatística. (2017) Informação estatística - Censos da população. [online] Lisboa: INE. Available at: https://www.ine.pt/xportal/ xmain?xpid=INE\&xpgid=I ne_base_dados.

[12] Jugović, A., Kovačić, M., \& Hadzic, A. (2011) Sustainable development model for nautical tourism ports. Tourism and Hospitality Management, 17(2), pp. 175-186.

[13] Landeta, J. (2006) Current validity of the Delphi method in social sciences. Technological Forecasting and Social Change, 73(5), pp. 467-482. doi: 10.1016/j.techfore.2005.09.002.

[14] Linstone, H. A., \& Turoff, M. (2002) The Delphi Method Techniques and applications. In: H. A. Linstone \& M. Turoff, eds., The delphi method - Techniques and applications. UNIDO.
[15] Luck, M. (2007) Nautical tourism development: opportunities and threats. In: M. Luck, ed., Nautical tourism: concepts and issues, New York: Cognizant Communication Corporation, pp. 3-13.

[16] Marine Traffic (2015) Traffic in 2014. [online] Available at: marinetraffic.com

[17] Marusic, Z., Horak, S., \& Sever, I. (2012) Tomas Nautika Jahting 2012. Zagreb.

[18] Ministarstvo Mora, Prometa I Infrastrukture Minitastvo Turizma (2008) Strategija razvoja nautičkog turizma. Zagreb: Ministarstvo Mora, Prometa I Infrastrukture Minitastvo Turizma.

[19] Moreira, C. (2012) A Técnica Delphi aplicada à investigação em turismo. In: R. Jacinto, ed., Patrimónios, territórios e turismo cultural: Recursos, estratégias e práticas. Guarda: Âncora Editora, Vol. 19, pp. 419-440.

[20] Moreira, C., \& Santos, N. (2010) New opportunities for water environments. River tourism and water leisure activities. In: E. Brito-Henriques, J. Sarmento, \& M. Lousada, eds., Water and tourism - Resources management, planning and sustainability, 1st ed., Lisbon: Centro de Estudos Geográficos, Universidade de Lisboa, pp. 147-168.

[21] Nunes, C. (2009) Figueira da Foz (1930-1960). Apontamentos sobre o turismo balnear. Universidade de Coimbra.

[22] Oliveira, J. M. (2013) Chegam de iate, são exigentes e gastam até 500 euros por dia. Diário de Notícias, pp. 24-25.

[23] Perna, F., Custódio, M. J., Gouveia, P., \& Oliveira, V. (2008) Perfil e potencial económico-social do turismo náutico no Algarve. (Comissão de Coordenação e Desenvolvimento Regional do Algarve, Ed.). Faro: SIG, Soc. Ind. Gráfica.

[24] Pforr, C., \& Dowling, R. (2009) Costal tourism development: planning and managing growth. In: R. Dowling \& C. Pforr, eds., Coastal tourism development. New York: Cognizant Communication Corporation, pp. 3-14.

[25] Sariisk, M., Turkay, O., \& Akova, O. (2011) How to manage yacht tourism in Turkey: a swot analysis and related stretgies, Procedia Social and Behavioral Sciences, 24, pp. 1014-1025.

[26] Silveira, L. (2016) O turismo de iates - Estratégia de desenvolvimento para a Figueira da Foz. Universidade de Coimbra.

[27] Sorokina, N. (2017) Tourism and water. Annals of Leisure Research, 20(3), pp. 389-391.

[28] Sousa, J. F., Fernandes, A., \& Carpinteiro, A. (2009) 0 desenvolvimento das actividades náuticas de recreio como estratégia de valorização territorial: um olhar sobre o estuário do Tejo. In: 1o Congresso de Desenvolvimento Regional de Cabo Verde. Cabo Verde - Redes e Desenvolvimento Regional, pp. 2475-2494.

[29] Tomás, P. (1988) Figueira da Foz do passado ao presente: elementos estatísticos subsidiários para o estudo do concelho da Figueira da Foz (história local 1080-1822). Figueira da Foz: Câmara Municipal da Figueira da Foz.

[30] Verdet, A. P. (2002) Puertos deportivos: repercusión de su administración y gestión em el desarrollo del turismo náutico. Estrategias para el caso de la Costa del Sol. Universidad de Málaga. 